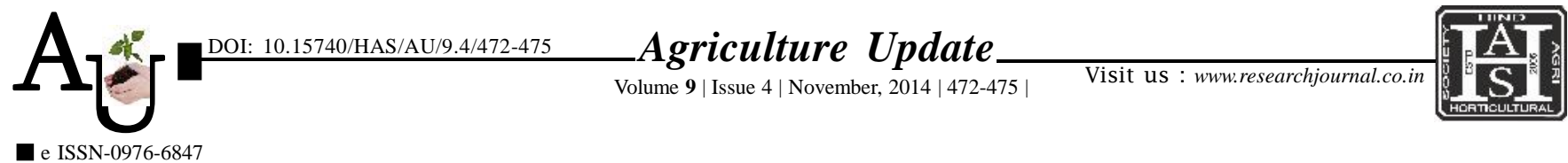

\title{
Research Article Impact of demonstrations of farmers fields in agro climatic zone II-A of Rajasthan
}

B.L. SHARMA AND K.C. SHARMA

Article Chronicle :

Received :

14.07.2014;

Revised :

21.08.2014;

Accepted :

06.09.2014

\section{KeY WoRdS:}

Impact,

Demonstrations,

Agro climatic zone mustard and wheat, respectively.
SUMMARY : An attempt has been made to study on impact of demonstration on farmers fields in adopted villages of Sikar district. The yield gap, input gap, cost and return were calculated for purpose of the study. The survey covered 40 farmers from 4 adopted villages where wheat, barley, gram and mustard demonstration (full technology) were conducted in adopted villages. In each village, 10 demonstrations were conducted. From each village, 10 farmers were selected who have adopted traditional practices for crop cultivation. The results indicated that yield gap per hectare between demonstration plots and farmers practices was 15.71, 23.70, 29.17 and 20.00 per cent for wheat, barley, gram and mustard, respectively. On farmers practices, overall inputs gap was about 21 per cent for wheat, barley and mustard and 33 per cent for gram as compared to demonstration. Thus, there is more scope to raise the mustard, gram, barley and wheat productivity by improving the techniques of production rather than by raising the input use levels. The results further revealed that the cost of cultivation per hectare on demonstration plots was Rs. 16854, Rs. 15110, Rs. 13622 and Rs. 12415 for wheat, barley, gram and mustard while on farmers fields it was Rs. 13883, Rs. 12445, Rs. 10301 and Rs. 10227 for wheat, barley, mustard and gram, respectively. The net return per hectare was the highest for mustard followed by wheat, barley and gram. While on farmers practices, it was highest for wheat followed by mustard, barley and gram. The increase of net return on demonstration plots over farmers' practices was $26.79,24.75,19.25$ and 9.43 per cent for barley, gram,

How to cite this article : Sharma, B.L. and Sharma, K.C. (2014). Impact of demonstrations of farmers fields in agro climatic zone II-A of Rajasthan. Agric. Update, 9(4): 472-475.
Author for correspondence :

\section{B.L. SHARMA}

Agricultural Research

Station, Fatehpur-

Shekhawati, SIKAR

(RAJASTHAN) INDIA

Email: arsfatehpur@

rediffmail.com

See end of the article for

authors' affiliations 